\title{
Carcass measurements, non-carcass components and cut production of local Brazilian Pantaneiro sheep and crossbreeds of Texel and Santa Inês with Pantaneiro
}

\author{
F.M. Vargas Junior ${ }^{\mathrm{a}, *}$, C.F. Martins ${ }^{\mathrm{b}}$, G.S. Pinto ${ }^{\mathrm{c}}$, M.B. Ferreira ${ }^{\mathrm{d}}$, H.A. Ricardo ${ }^{\mathrm{a}}$, \\ A.P. Leonardo ${ }^{a}$, A.R.M. Fernandes ${ }^{a}$, A. Teixeira ${ }^{\mathrm{e}}$ \\ a Faculdade de Ciências Agrárias (FCA), Universidade Federal da Grande Dourados (UFGD), Caixa Postal 533, \\ 79804-970 Dourados, MS, Brazil \\ b Faculdade de Veterinária, Universidade Federal de Pelotas, Campus Universitário s/n, Caixa Postal 354, Capão do Leão, \\ 96010-900 Pelotas, RS, Brazil \\ c Private Veterinarian, Brazil \\ d Universidade Anhanguera-Uniderp, Campus III, Rua Professor Alexandre Herculano, 1400, Jardim Veraneio, \\ 79037280 Campo Grande, MS, Brazil \\ e CECAV - Centro de Ciência Animal e Veterinária da Universidade de Trás-os-Montes e Alto Douro, Escola Superior Agrária de Bragança, \\ Campus de Santa Apolónia, Apartado 1172, 5301-855 Bragança, Portugal
}

\section{A R T I C L E I N F O}

\section{Article history:}

Received 15 May 2014

Received in revised form

15 September 2014

Accepted 18 December 2014

Available online 31 December 2014

\section{Keywords:}

Sheep breeds

Crossbreds

Internal fat

Meat cut

\begin{abstract}
A B S T R A C T
This study aimed to assess and compare the non-carcass components, carcass measurements and meat cut production of Pantaneiro (P) sheep and their Texel (TP) and Santa Inês (SIP) crossbreds. Ninety-six lambs, of which 51 were male and 45 were female, with a mean weaning weight of $15.21 \pm 1.25 \mathrm{~kg}$ and age of $78 \pm 13$ days were slaughtered at $32 \mathrm{~kg}$ of body weight. TP lambs had greater leg compactness and weight and percentage of pelt, whereas genotypes (G) P and SIP had higher carcass depth. P and SIP females had weights omental fat percentages that were superior to the other animals, whereas SIP females had higher mesenteric fat. TP males had higher production of white viscera. There was no effect of sex, G or interaction for production and percentage of all meat cuts. Pantaneiro lambs and their crosses with meat breeds could be useful in meat production systems under Savannah environmental conditions.
\end{abstract}

(c) 2015 Elsevier B.V. All rights reserved.

\section{Introduction}

Most domesticated livestock species were introduced in Brazil by successive waves of early exploration and colonization. For almost five centuries, these species, including sheep breeds, have been naturally selected in distinct environments in such a way that today they present

\footnotetext{
* Corresponding author at: Rodovia Dourados à Itahum, km 12, Cidade Universitária, Dourados, MS, Brazil. Tel.: +55 6734102352.

E-mail address: fernandojunior@ufgd.edu.br (F.M. Vargas Junior).
}

characteristics adapted to their specific environmental conditions. The breeds developed in Brazil are known as "Criollo", "local," or naturalized (Mariante and Egito, 2002).

The Pantaneiro sheep is a small to medium-sized breed reared in the Pantanal region of Brazil. This region is characterized by a tropical climate with a dry winter season and rainy summer. The Pantaneiro breed has a combination of alleles from wool breeds from the south of Brazil and hair sheep breeds from the semiarid northeast region. According to Vargas Junior et al. (2011), Pantaneiro females have high maternal ability and no reproductive seasonality, and lambs have high productive potential in terms of carcass 
traits and meat quality. The work of Crispim et al. (2013) shows that compared to other populations, the Pantaneiro breed represents a reservoir of genetic diversity with rare and useful alleles for genetic improvement, which highlights the importance of preserving the breed.

Since the beginning of the 20th century, some exotic breeds have been imported from temperate regions for meat purposes. Although more productive, these breeds did not have adaptive traits that are found in local breeds, such as resistance to diseases, parasites, and climate. Even so, little by little, the exotic breeds replaced the native breeds to such an extent that native breeds, such as Morada Nova, a breed of hair sheep, are now in danger of extinction (Mariante and Egito, 2002).

Studies from Brazil (Souza et al., 2013), Czech Republic (Kuchtík et al., 2012), Iran (Esmailizadeh et al., 2012; Yousefi et al., 2012), Tunisia (Bedhiaf-Romdhani et al., 2008), and Turkey (Ekiz et al., 2009, 2012; Gökdal et al., 2012; Yakan and Ünal, 2010) have assessed the performance of local breeds and crossbreeds in different production systems. The findings of these studies provide evidence that local breeds can be used as an alternative to crossbreeds without negative effects on productivity and highlight the importance of the maintenance of genetic resources from local breeds.

The aim of the present study was to assess the effect of Pantaneiro sheep and their crossings with Texel and Santa Inês sheep on carcass and non-carcass components as well as on cut proportions to provide information to breeders, retailers and consumers.

\section{Materials and methods}

The experiment was performed at the Sheep Technologic Center of the "Três Barras" experimental farm of the University for the Development of the State and the Region of Pantanal (UNIDERP) in the Campo Grande city of the Mato Grosso do Sul state in Brazil. The climate of the region, using the Köppen classification, is Tropical Savanna or tropical wet and dry climate with a monthly mean temperature above $18^{\circ} \mathrm{C}\left(64^{\circ} \mathrm{F}\right)$ for every month of the year and typically a pronounced dry season, with the driest month having precipitation less than $60 \mathrm{~mm}$.

\subsection{Animal sampling and diets}

A total of 96 lambs, of which 51 were male and 45 were female, with weaning weights ranging from $15.21 \pm 1.25 \mathrm{~kg}$ and ages $78 \pm 13$ days, of the "Pantaneiro" group and Texel and Santa Inês crossbreds were included in the study. The distribution of lambs by sex and genetic group was 17 male and 12 female Pantaneiro (P) sheep, 16 male and 13 female Texel $\times$ Pantaneiro (TP), and 18 male and 20 female Santa Inês $\times$ Pantaneiro (SIP). Lambs were housed and fed with a balanced ration to achieve an average daily gain (ADG) of $250 \mathrm{~g}$ following the NRC (2007) recommendations.

Lambs were fed twice a day at $0830 \mathrm{~h}$ and $1600 \mathrm{~h}$ (in the morning and afternoon), with quantities adjusted daily to yield 10 and $20 \%$, respectively, of the total feed offered, which was weighed to determine the daily dry matter intake (DMI, $\mathrm{kg} \mathrm{day}^{-1}$ ). The DM composition of the diet was $60 \%$ concentrate and $40 \%$ roughage in the form of corn silage. The ration formulation was $47.88 \%$ ground corn, $32.92 \%$ soybean meal, $15 \%$ wheat bran, $0.1 \%$ probiotic (Biosaf, Saccharomyces cerevisiae, Lesaffre, France), $2 \%$ mineral salts, $2 \%$ calcium carbonate and $0.1 \%$ vitamins $\mathrm{A}, \mathrm{D}$ and $\mathrm{E}$. The animals were weighed after $12 \mathrm{~h}$ fasting every 21 days until slaughter.

Table 1

The effect of sex $(\mathrm{S})$ and genotype on the weight $(\mathrm{kg})$ of body components.

\begin{tabular}{|c|c|c|c|c|c|c|c|}
\hline \multirow[t]{2}{*}{ Items } & \multicolumn{3}{|l|}{ Genotype (G) } & \multirow[t]{2}{*}{ Mean } & \multicolumn{3}{|l|}{$\mathrm{P}$} \\
\hline & $\mathrm{P}$ & TP & SIP & & $\mathrm{S}$ & G & $\mathrm{S} \times \mathrm{G}$ \\
\hline Blood & & & & & NS & NS & NS \\
\hline Male & $1.28 \pm 0.14$ & $1.25 \pm 0.23$ & $1.44 \pm 0.23$ & $1.33 \pm 0.22$ & & & \\
\hline Female & $1.27 \pm 0.18$ & $1.25 \pm 0.20$ & $1.22 \pm 0.23$ & $1.24 \pm 0.20$ & & & \\
\hline Mean & $1.27 \pm 0.15$ & $1.25 \pm 0.21$ & $1.33 \pm 0.25$ & & & & \\
\hline Pelt & & & & & NS & ** & NS \\
\hline Male & $3.31 \pm 0.73$ & $3.94 \pm 0.87$ & $3.33 \pm 0.76$ & $3.52 \pm 0.83$ & & & \\
\hline Female & $3.42 \pm 0.52$ & $3.60 \pm 0.51$ & $2.74 \pm 0.57$ & $3.17 \pm 0.66$ & & & \\
\hline Mean & $3.35^{B} \pm 0.65$ & $3.79^{\mathrm{A}} \pm 0.74$ & $3.00^{C} \pm 0.72$ & & & & \\
\hline Limbs & & & & & $* * *$ & NS & NS \\
\hline Male & $0.75^{\mathrm{A}} \pm 0.10$ & $0.77^{\mathrm{A}} \pm 0.08$ & $0.83^{A} \pm 0.08$ & $0.78 \pm 0.09$ & & & \\
\hline Female & $0.69^{B} \pm 0.07$ & $0.67^{\mathrm{B}} \pm 0.04$ & $0.69^{B} \pm 0.06$ & $0.69 \pm 0.06$ & & & \\
\hline Mean & $0.73 \pm 0.09$ & $0.72 \pm 0.08$ & $0.75 \pm 0.10$ & & & & \\
\hline Head & & & & & NS & NS & NS \\
\hline Male & $1.40 \pm 0.09$ & $1.41 \pm 0.16$ & $1.44 \pm 0.26$ & $1.42 \pm 0.18$ & & & \\
\hline Female & $1.30 \pm 0.12$ & $1.35 \pm 0.12$ & $1.32 \pm 0.11$ & $1.32 \pm 0.12$ & & & \\
\hline Mean & $1.36 \pm 0.11$ & $1.38 \pm 0.15$ & $1.37 \pm 0.20$ & & & & \\
\hline Testicle/Udder & & & & & *** & * & NS \\
\hline Male & $0.40^{A} \pm 0.12$ & $0.31^{\mathrm{A}} \pm 0.09$ & $0.38 \pm 0.14$ & $0.36 \pm 0.12$ & & & \\
\hline Female & $0.11^{\mathrm{B}} \pm 0.02$ & $0.08^{\mathrm{B}} \pm 0.02$ & $0.26 \pm 0.39$ & $0.24 \pm 0.15$ & & & \\
\hline Mean & $0.35^{A} \pm 0.16$ & $0.22^{\mathrm{B}} \pm 0.13$ & $0.34^{\mathrm{A}} \pm 0.25$ & & & & \\
\hline Reproductive organs & & & & & NS & * & NS \\
\hline Male & $0.09 \pm 0.02$ & $0.14 \pm 0.05$ & $0.18 \pm 0.14$ & $0.14 \pm 0.09$ & & & \\
\hline Female & $0.09 \pm 0.03$ & $0.09 \pm 0.04$ & $0.13 \pm 0.09$ & $0.10 \pm 0.07$ & & & \\
\hline Mean & $0.09^{B} \pm 0.03$ & $0.11^{\mathrm{AB}} \pm 0.05$ & $0.14^{\mathrm{A}} \pm 0.11$ & & & & \\
\hline
\end{tabular}

P, Pantaneiro; TP, Texel $\times$ Pantaneiro; SIP, Santa Inês $\times$ Pantaneiro; NS, not significant.

For sex within $\mathrm{G}$, means with different capitalized italic superscripts differ.

For $G$, means with different capitalized superscripts differ.

For $\mathrm{S} \times \mathrm{G}$, means with different lower-case superscripts differ.

${ }^{*} P<0.05$.

${ }^{* *} P<0.01$

${ }^{* * * *} P<0.0001$. 
Table 2

The effect of sex (S) and genotype on the percentage (\%) of body components.

\begin{tabular}{|c|c|c|c|c|c|c|c|}
\hline \multirow[t]{2}{*}{ Items } & \multicolumn{3}{|l|}{ Genotype (G) } & \multirow[t]{2}{*}{ Mean } & \multicolumn{3}{|l|}{$P$} \\
\hline & $\mathrm{P}$ & $\mathrm{TP}$ & SIP & & $\mathrm{S}$ & G & $\mathrm{S} \times \mathrm{G}$ \\
\hline Blood & & & & & NS & NS & NS \\
\hline Male & $4.46 \pm 0.35$ & $4.31 \pm 0.71$ & $4.72 \pm 0.60$ & $4.50 \pm 0.58$ & & & \\
\hline Female & $4.24 \pm 0.38$ & $4.23 \pm 0.53$ & $4.34 \pm 0.60$ & $4.28 \pm 0.53$ & & & \\
\hline Mean & $4.37 \pm 0.37$ & $4.27 \pm 0.62$ & $4.51 \pm 0.63$ & & & & \\
\hline Pelt & & & & & NS & $* * *$ & NS \\
\hline Male & $11.50 \pm 2.20$ & $13.51 \pm 2.52$ & $10.94 \pm 2.11$ & $11.96 \pm 2.49$ & & & \\
\hline Female & $11.49 \pm 1.54$ & $12.23 \pm 1.61$ & $9.77 \pm 1.95$ & $10.94 \pm 2.03$ & & & \\
\hline Mean & $11.49^{\mathrm{B}} \pm 1.93$ & $12.94^{\mathrm{A}} \pm 2.22$ & $10.29^{C} \pm 2.08$ & & & & \\
\hline Limbs & & & & & $* * *$ & * & NS \\
\hline Male & $2.62^{\mathrm{A}} \pm 0.28$ & $2.63^{A} \pm 0.18$ & $2.72^{\mathrm{A}} \pm 0.26$ & $2.66 \pm 0.24$ & & & \\
\hline Female & $2.34^{\mathrm{B}} \pm 0.24$ & $2.27^{\mathrm{B}} \pm 0.12$ & $2.47^{\mathrm{B}} \pm 0.15$ & $2.38 \pm 0.19$ & & & \\
\hline Mean & $2.51^{\mathrm{AB}} \pm 0.30$ & $2.47^{\mathrm{B}} \pm 0.24$ & $2.58^{\mathrm{A}} \pm 0.24$ & & & & \\
\hline Head & & & & & NS & NS & NS \\
\hline Male & $4.92 \pm 0.44$ & $4.85 \pm 0.45$ & $4.73 \pm 0.82$ & $4.83 \pm 0.59$ & & & \\
\hline Female & $4.38 \pm 0.34$ & $4.60 \pm 0.41$ & $4.70 \pm 0.42$ & $4.59 \pm 0.41$ & & & \\
\hline Mean & $4.70 \pm 0.48$ & $4.74 \pm 0.44$ & $4.71 \pm 0.63$ & & & & \\
\hline Testicle/Udder & & & & & $* * *$ & NS & NS \\
\hline Male & $1.40^{\mathrm{A}} \pm 0.39$ & $1.03^{\mathrm{A}} \pm 0.21$ & $1.23 \pm 0.45$ & $1.23 \pm 0.39$ & & & \\
\hline Female & $0.23^{\mathrm{B}} \pm 0.19$ & $0.28^{\mathrm{B}} \pm 0.08$ & $0.84 \pm 1.37$ & $0.47 \pm 0.85$ & & & \\
\hline Mean & $1.11 \pm 0.62$ & $0.74 \pm 0.41$ & $1.09 \pm 0.88$ & & & & \\
\hline Reproductive organs & & & & & NS & * & NS \\
\hline Male & $0.33 \pm 0.08$ & $0.48 \pm 0.16$ & $0.60 \pm 0.45$ & $0.46 \pm 0.28$ & & & \\
\hline Female & $0.29 \pm 0.12$ & $0.30 \pm 0.14$ & $0.45 \pm 0.33$ & $0.36 \pm 0.25$ & & & \\
\hline Mean & $0.31^{\mathrm{B}} \pm 0.10$ & $0.38^{\mathrm{AB}} \pm 0.18$ & $0.49^{\mathrm{A}} \pm 0.37$ & & & & \\
\hline
\end{tabular}

P, Pantaneiro; TP, Texel $\times$ Pantaneiro; SIP, Santa Inês $\times$ Pantaneiro; NS, not significant.

For sex within $\mathrm{G}$, means with different capitalized italic superscripts differ.

For $\mathrm{G}$, means with different capitalized superscripts differ.

For $\mathrm{S} \times \mathrm{G}$, means with different lower-case superscripts differ.

${ }^{*} P<0.05$.

${ }^{* *} P<0.01$.

${ }^{* * *} P<0.0001$

When lambs reached a body weight of approximately $32 \mathrm{~kg}$, they were slaughtered after a $12 \mathrm{~h}$ fast.

\subsection{Non-carcass components}

After slaughter, the non-carcass components were separated and weighed as follows: body components (blood, hide and pelt, feet, head and reproductive organs) gut fat depots (omental, mesenteric, perinephric and retro-peritoneal) red viscera (heart, liver, gallbladder, pancreas, spleen, bladder, and kidneys) white viscera (esophagus, rumen-reticulum, omasum, abomasum, small intestine, and large intestine).

\subsection{Carcass measurements and meat cuts}

After the carcasses were chilled for $24 \mathrm{~h}$ at $4{ }^{\circ} \mathrm{C}$, they were suspended by a gamble of constant width between legs and the following measurements (Pálsson, 1939; Boccard et al., 1964; Kempster et al., 1986) were assessed: rump perimeter $(B)$, rump width $(G)$, internal carcass length $(L)$, leg length $(F)$ and carcass depth $(\mathrm{Th})$. The indexes of carcass compactness (cold carcass weight/L) and leg compactness $(\mathrm{G} / \mathrm{F})$ were calculated. The left side of the carcass was divided into the following commercial meat cuts: neck, shoulder, ribs, breast, loin and leg. The percentages of meat cuts in relation to carcass weight were calculated.

\subsection{Statistical analysis}

Statistical analyses were performed using SAS 9.2 (SAS Institute, Cary, NC, USA). The experimental design was a factorial fully randomized with three genotypes $(\mathrm{P} \times \mathrm{TP} \times \mathrm{SIP})$ and two sexes (male and female). The normality of the data was verified using the Shapiro-Wilk test and the homogeneity of variances was verified using the Bartlett test. The significance of differences between sexes $(S)$ or genotypes $(G)$ and the interactions $(S \times G)$ were verified using the Tukey test with a significance level of $5 \%$.

\section{Results}

The effect of sex (S) and genotype on the weight $(\mathrm{kg})$ and percentage (\%) of body components are shown in Tables 1 and 2. There was a significant genotype effect for hide and reproductive organs and the TP lambs had higher hide values than Pantaneiro and SIP lambs. The SIP lambs had higher $(P<0.05)$ reproductive organ weights than Pantaneiro lambs.

There was a sex effect for limb weight (Table 1) and a genotype effect for limb yield (Table 2). Males had higher weight and limb yields, independent of genotype, but the SIP lambs had higher limb yields than the TP lambs. There was also a sex effect on testicle/udder weight and a genotype effect for the testicle/udder yield; male P and TP lambs had higher values than females for these characteristics and the lowest testicle/udder weight was observed for Texel lambs.

The means and standard deviations of weight and yields of fat and viscera for the different genotype/sex groups are shown in Tables 3 and 4. There was a highly significant sex effect on the omental, mesenteric, perinephric and retro-peritoneal fats $(P<0.0001)$ and a significant effect on red viscera $(P<0.05)$. Females had higher omental and perinephric and retro-peritoneal fat weights than males, independent of genotype. Significant sex differences for mesenteric fat were only found for the Pantaneiro group. The SIP males had higher white viscera weights than females. 
Table 3

The effect of sex $(\mathrm{S})$ and genotype on the weight $(\mathrm{kg})$ of fat and viscera.

\begin{tabular}{|c|c|c|c|c|c|c|c|}
\hline \multirow[t]{2}{*}{ Items } & \multicolumn{3}{|l|}{ Genotype (G) } & \multirow[t]{2}{*}{ Mean } & $\mathrm{P}$ & \multirow[b]{2}{*}{ G } & \multirow[b]{2}{*}{$\mathrm{S} \times \mathrm{G}$} \\
\hline & $\mathrm{P}$ & $\mathrm{TP}$ & SIP & & $\mathrm{S}$ & & \\
\hline Omental fat & & & & & $* * *$ & $* * * *$ & $*$ \\
\hline Male & $0.46^{\mathrm{cd}} \pm 0.20$ & $0.38^{\mathrm{d}} \pm 0.19$ & $0.63^{\mathrm{b}} \pm 0.27$ & $0.49 \pm 0.24$ & & & \\
\hline Female & $0.92^{\mathrm{a}} \pm 0.28$ & $0.54^{\mathrm{bc}} \pm 0.13$ & $0.84^{\mathrm{a}} \pm 0.21$ & $0.78 \pm 0.26$ & & & \\
\hline Mean & $0.65^{\mathrm{A}} \pm 0.32$ & $0.45^{\mathrm{B}} \pm 0.18$ & $0.75^{\mathrm{A}} \pm 0.26$ & & & & \\
\hline Mesenteric fat & & & & & ** & * & NS \\
\hline Male & $0.28^{\mathrm{B}} \pm 0.08$ & $0.29 \pm 0.07$ & $0.35 \pm 0.16$ & $0.31 \pm 0.11$ & & & \\
\hline Female & $0.38^{\mathrm{A}} \pm 0.12$ & $0.33 \pm 0.07$ & $0.41 \pm 0.11$ & $0.38 \pm 0.10$ & & & \\
\hline Mean & $0.33^{\mathrm{B}} \pm 0.11$ & $0.31^{\mathrm{B}} \pm 0.07$ & $0.38^{A} \pm 0.13$ & & & & \\
\hline Perinephric and Retroperitoneal fat & & & & & $* * *$ & *** & NS \\
\hline Male & $0.37^{\mathrm{B}} \pm 0.10$ & $0.24^{\mathrm{B}} \pm 0.18$ & $0.44^{\mathrm{B}} \pm 0.14$ & $0.35 \pm 0.16$ & & & \\
\hline Female & $0.68^{A} \pm 0.29$ & $0.40^{\mathrm{A}} \pm 0.14$ & $0.77^{\mathrm{A}} \pm 0.19$ & $0.66 \pm 0.26$ & & & \\
\hline Mean & $0.49^{\mathrm{B}} \pm 0.24$ & $0.30^{C} \pm 0.18$ & $0.63^{\mathrm{A}} \pm 0.24$ & & & & \\
\hline Red viscera & & & & & $*$ & NS & NS \\
\hline Male & $1.04 \pm 0.12$ & $1.09 \pm 0.13$ & $1.20^{\mathrm{A}} \pm 0.22$ & $1.11 \pm 0.18$ & & & \\
\hline Female & $1.04 \pm 0.19$ & $1.03 \pm 0.14$ & $1.03^{\mathrm{B}} \pm 0.11$ & $1.03 \pm 0.14$ & & & \\
\hline Mean & $1.04 \pm 0.15$ & $1.06 \pm 0.13$ & $1.11 \pm 0.19$ & & & & \\
\hline White viscera & & & & & NS & NS & $*$ \\
\hline Male & $2.02^{\mathrm{b}} \pm 0.23$ & $2.30^{\mathrm{a}} \pm 0.34$ & $2.08^{b} \pm 0.29$ & $2.13 \pm 0.31$ & & & \\
\hline Female & $2.12^{\mathrm{ab}} \pm 0.32$ & $1.95^{b} \pm 0.25$ & $1.99^{\mathrm{b}} \pm 0.23$ & $2.01 \pm 0.26$ & & & \\
\hline Mean & $2.06 \pm 0.27$ & $2.14 \pm 0.35$ & $2.03 \pm 0.26$ & & & & \\
\hline
\end{tabular}

P, Pantaneiro; TP, Texel $\times$ Pantaneiro; SIP, Santa Inês $\times$ Pantaneiro; NS, not significant.

Red viscera: sum of trachea, heart, liver, gallbladder, pancreas, spleen, bladder, and kidneys.

White viscera: sum of esophagus, rumen-reticulum, omasum, abomasum, small intestine, and large intestine.

For sex within $G$, means with different capitalized italic superscripts differ.

For G, means with different capitalized superscripts differ.

For $\mathrm{S} \times \mathrm{G}$, means with different lower-case superscripts differ.

${ }^{*} P<0.05$.

** $P<0.01$.

*** $P<0.0001$.

Table 4

The effects of sex (S) and genotype on the percentage (\%) of fat and viscera.

\begin{tabular}{|c|c|c|c|c|c|c|c|}
\hline \multirow[t]{2}{*}{ Items } & \multicolumn{3}{|l|}{ Genotype (G) } & \multirow[t]{2}{*}{ Mean } & \multicolumn{3}{|l|}{$\mathrm{P}$} \\
\hline & $P$ & $\mathrm{TP}$ & SIP & & $S$ & G & $\mathrm{S} \times \mathrm{G}$ \\
\hline Omental fat & & & & & $* * *$ & ${ }^{* * *}$ & * \\
\hline Male & $1.61^{\mathrm{bc}} \pm 0.64$ & $1.29^{c} \pm 0.65$ & $2.04^{\mathrm{b}} \pm 0.83$ & $1.65 \pm 0.76$ & & & \\
\hline Female & $3.09^{a} \pm 0.87$ & $1.85^{\mathrm{b}} \pm 0.43$ & $2.97^{\mathrm{a}} \pm 0.58$ & $2.68 \pm 0.82$ & & & \\
\hline Mean & $2.20^{\mathrm{B}} \pm 1.03$ & $1.54^{\mathrm{C}} \pm 0.62$ & $2.55^{\mathrm{A}} \pm 0.84$ & & & & \\
\hline Mesenteric fat & & & & & ** & * & NS \\
\hline Male & $0.99^{\mathrm{B}} \pm 0.29$ & $1.01 \pm 0.23$ & $1.13^{\mathrm{B}} \pm 0.42$ & $1.04 \pm 0.32$ & & & \\
\hline Female & $1.27^{\mathrm{A}} \pm 0.36$ & $1.14 \pm 0.27$ & $1.44^{\mathrm{A}} \pm 0.29$ & $1.31 \pm 0.33$ & & & \\
\hline Mean & $1.11^{\mathrm{B}} \pm 0.35$ & $1.07^{\mathrm{B}} \pm 0.25$ & $1.31^{\mathrm{A}} \pm 0.38$ & & & & \\
\hline Perinephric and Retroperitoneal fat & & & & & ${ }^{* * *}$ & ${ }^{* * * *}$ & * \\
\hline Male & $1.28^{\mathrm{c}} \pm 0.27$ & $0.80^{\mathrm{d}} \pm 0.61$ & $1.42^{c} \pm 0.33$ & $1.17 \pm 0.49$ & & & \\
\hline Female & $2.28^{\mathrm{b}} \pm 0.86$ & $1.33^{c} \pm 0.44$ & $2.73^{a} \pm 0.55$ & $2.27 \pm 0.84$ & & & \\
\hline Mean & $1.66^{\mathrm{B}} \pm 0.74$ & $1.01^{C} \pm 0.60$ & $2.17^{\mathrm{A}} \pm 0.81$ & & & & \\
\hline Red viscera & & & & & NS & NS & NS \\
\hline Male & $3.64 \pm 0.32$ & $3.74 \pm 032$ & $3.93 \pm 0.60$ & $3.77 \pm 0.44$ & & & \\
\hline Female & $3.49 \pm 0.45$ & $3.51 \pm 0.47$ & $3.66 \pm 0.35$ & $3.57 \pm 0.41$ & & & \\
\hline Mean & $3.58 \pm 0.38$ & $3.64 \pm 0.40$ & $3.79 \pm 0.49$ & & & & \\
\hline White viscera & & & & & NS & NS & $* *$ \\
\hline Male & $7.05^{\mathrm{b}} \pm 0.71$ & $7.89^{\mathrm{a}} \pm 1.04$ & $6.82^{\mathrm{b}} \pm 0.98$ & $7.24 \pm 1.01$ & & & \\
\hline Female & $7.12^{\mathrm{b}} \pm 0.80$ & $6.65^{b} \pm 0.90$ & $7.11^{b} \pm 1.04$ & $6.98 \pm 0.94$ & & & \\
\hline Mean & $7.08 \pm 0.73$ & $7.33 \pm 1.15$ & $6.98 \pm 1.01$ & & & & \\
\hline
\end{tabular}

P, Pantaneiro; TP, Texel $\times$ Pantaneiro; SIP, Santa Inês $\times$ Pantaneiro; NS, not significant.

Red viscera: sum of trachea, heart, liver, gallbladder, pancreas, spleen, bladder, and kidneys.

White viscera: sum of esophagus, rumen-reticulum, omasum, abomasum, small intestine, and large intestine.

For sex within $\mathrm{G}$, means with different capitalized italic superscripts differ.

For $\mathrm{G}$, means with different capitalized superscripts differ.

For $\mathrm{S} \times \mathrm{G}$, means with different lower-case superscripts differ.

${ }^{*} P<0.05$.

** $P<0.01$.

*** $P<0.0001$. 
Table 5

The effects of sex $(S)$ and genotype on carcass measurements.

\begin{tabular}{|c|c|c|c|c|c|c|c|}
\hline \multirow[t]{2}{*}{ Items } & \multicolumn{3}{|l|}{ Genotype (G) } & \multirow[t]{2}{*}{ Mean } & \multicolumn{3}{|l|}{$\mathrm{P}$} \\
\hline & $\mathrm{P}$ & $\mathrm{TP}$ & SIP & & $\mathrm{S}$ & G & $\mathrm{S} \times \mathrm{G}$ \\
\hline $\mathrm{B}, \mathrm{cm}$ & & & & & NS & NS & NS \\
\hline Male & $60.61 \pm 2.35$ & $61.72 \pm 2.89$ & $61.09 \pm 2.37$ & $61.12 \pm 2.53$ & & & \\
\hline Female & $62.42 \pm 2.93$ & $62.77 \pm 2.71$ & $61.68 \pm 2.74$ & $62.19 \pm 2.76$ & & & \\
\hline Mean & $61.33 \pm 2.70$ & $62.19 \pm 2.81$ & $61.41 \pm 2.56$ & & & & \\
\hline $\mathrm{G}, \mathrm{cm}$ & & & & & NS & NS & NS \\
\hline Male & $21.78 \pm 0.91$ & $22.94 \pm 1.50$ & $22.58 \pm 1.80$ & $22.41 \pm 1.50$ & & & \\
\hline Female & $23.00 \pm 1.28$ & $23.08 \pm 0.95$ & $22.83 \pm 1.37$ & $22.94 \pm 1.22$ & & & \\
\hline Mean & $22.27 \pm 1.22$ & $23.00 \pm 1.27$ & $22.71 \pm 1.56$ & & & & \\
\hline $\mathrm{L}, \mathrm{cm}$ & & & & & NS & NS & NS \\
\hline Male & $60.67 \pm 3.79$ & $59.19 \pm 3.04$ & $61.29 \pm 2.37$ & $60.41 \pm 3.19$ & & & \\
\hline Female & $60.92 \pm 3.18$ & $59.54 \pm 2.63$ & $60.15 \pm 2.81$ & $60.18 \pm 2.85$ & & & \\
\hline Mean & $60.77 \pm 3.50$ & $59.34 \pm 2.82$ & $60.68 \pm 2.65$ & & & & \\
\hline $\mathrm{F}, \mathrm{cm}$ & & & & & NS & $* * *$ & NS \\
\hline Male & $26.83 \pm 1.76$ & $24.53 \pm 1.56$ & $28.12 \pm 1.58$ & $26.54 \pm 2.18$ & & & \\
\hline Female & $26.25 \pm 1.76$ & $25.15 \pm 0.99$ & $27.38 \pm 0.99$ & $26.43 \pm 1.54$ & & & \\
\hline Mean & $26.60^{\mathrm{B}} \pm 1.75$ & $24.81^{C} \pm 1.35$ & $27.72^{\mathrm{A}} \pm 1.33$ & & & & \\
\hline $\mathrm{Th}, \mathrm{cm}$ & & & & & NS & ${ }^{* *}$ & NS \\
\hline Male & $25.81 \pm 1.74$ & $25.25 \pm 1.58$ & $26.74 \pm 1.83$ & $25.94 \pm 1.80$ & & & \\
\hline Female & $26.46 \pm 1.72$ & $25.08 \pm 0.86$ & $26.43 \pm 1.64$ & $26.04 \pm 1.58$ & & & \\
\hline Mean & $26.07^{A} \pm 1.74$ & $25.17^{\mathrm{B}} \pm 1.29$ & $26.57^{\mathrm{A}} \pm 1.71$ & & & & \\
\hline $\mathrm{CC}, \mathrm{kg} \mathrm{cm}^{-1}$ & & & & & NS & NS & NS \\
\hline Male & $0.26 \pm 0.02$ & $0.26 \pm 0.03$ & $0.27 \pm 0.03$ & $0.27 \pm 0.03$ & & & \\
\hline Female & $0.27 \pm 0.03$ & $0.27 \pm 0.03$ & $0.27 \pm 0.03$ & $0.27 \pm 0.03$ & & & \\
\hline Mean & $0.26 \pm 0.03$ & $0.26 \pm 0.03$ & $0.27 \pm 0.03$ & & & & \\
\hline $\mathrm{LC}, \mathrm{kg} \mathrm{cm}^{-1}$ & & & & & NS & * & $*$ \\
\hline Male & $0.76^{\mathrm{b}} \pm 0.08$ & $0.85^{\mathrm{a}} \pm 0.10$ & $0.73^{\mathrm{b}} \pm 0.10$ & $0.78 \pm 0.10$ & & & \\
\hline Female & $0.80^{\mathrm{ab}} \pm 0.11$ & $0.75^{\mathrm{b}} \pm 0.07$ & $0.73^{b} \pm 0.09$ & $0.76 \pm 0.09$ & & & \\
\hline Mean & $0.77^{\mathrm{AB}} \pm 0.09$ & $0.80^{\mathrm{A}} \pm 0.10$ & $0.73^{\mathrm{B}} \pm 0.09$ & & & & \\
\hline
\end{tabular}

P, Pantaneiro; TP, Texel $\times$ Pantaneiro; SIP, Santa Inês $\times$ Pantaneiro; NS, not significant.

B, Buttock perimeter; G, Buttock circumference; L, Internal carcass length; F, Leg length; Th, Thoracic depth; CC, Carcass compactness; LC, Leg compactness. For sex within $\mathrm{G}$, means with different capitalized italic superscripts differ.

For $\mathrm{G}$, means with different capitalized superscripts differ.

For $\mathrm{S} \times \mathrm{G}$, means with different lower-case superscripts differ.

${ }^{*} P<0.05$.

** $P<0.01$.

*** $P<0.0001$

$P$ and SIP lambs had significantly higher $(P<0.0001)$ omental fat weight than TP lambs. TP and P lambs had lower $(P<0.05)$ mesenteric fat weights compared to SIP lambs. The three genotypes had significantly different perinephric and retro-peritoneal weights, with the highest values for SIP lambs, followed by P and TP lambs (Table 5). There was a significant interaction between genotype and sex for omental fat and white viscera weights. The P and SIP females had higher values than SIP males, TP females and P males.

There were significant sex and genotype effects for omental, mesenteric, and perinephric and retroperitoneal fat percentages (Table 4). Females had a significantly higher fat components than males $(P<0.01)$, and SIP lambs had higher percentages than $P$ and TP lambs. The use of Texel genotype provided lower omental and perinephric and retroperitoneal fat percentages.

We observed an interaction between sex and genotype for omental, perinephric and retroperitoneal, and white viscera percentages (Table 4). P and SIP females had the highest omental fat percentages, followed by SIP males and TP females; there were no differences between $P$ males and TP males. SIP females had higher perinephric and retroperitoneal fat percentages and TP males with the lowest value. TP males had the highest white viscera percentages; the white viscera percentage did not differ between $\mathrm{P}$ and SIP males or P, TP and SIP females.

The means and standard deviations of carcass measurements of different sex/genotypes are shown in Table 5 . There were only significant differences between genotypes for F, Th and LC measurements. SIP lambs had higher $(P<0.0001) F$ measurement than $P$ and TP lambs. P and SIP lambs had higher Th measurement than TP lambs. There was a significant difference for LC index between TP and SIP lambs and a significant interaction between genotype and sex was found. The TP males had a higher LC index compared to P and SIP males or TP and SIP females. The means and standard deviations of meat cut weights and yields are shown in Tables 6 and 7; there were no significant differences found between sexes or genotypes.

\section{Discussion}

The use of adapted sheep favors the maintenance of production systems on the basis of low nutritional and management requirements. According to Galal et al. (1993), the use of specialized genotypes for meat production becomes feasible for the intensification of production systems based on local or native genotypes. The Pantaneiro genetic group of sheep presents possibilities for use in 
Table 6

The effect of sex (S) and genotype on cut weights (kg).

\begin{tabular}{|c|c|c|c|c|c|c|c|}
\hline \multirow[t]{2}{*}{ Items } & \multicolumn{3}{|l|}{ Genotype (G) } & \multirow[t]{2}{*}{ Mean } & \multicolumn{3}{|l|}{$\mathrm{P}$} \\
\hline & $\mathrm{P}$ & $\mathrm{TP}$ & SIP & & $\mathrm{S}$ & G & $\overline{\mathrm{S} \times \mathrm{G}}$ \\
\hline Neck & & & & & NS & NS & NS \\
\hline Male & $1.14 \pm 0.19$ & $1.15 \pm 0.27$ & $1.27 \pm 0.24$ & $1.18 \pm 0.24$ & & & \\
\hline Female & $1.16 \pm 0.27$ & $1.02 \pm 0.15$ & $1.12 \pm 0.23$ & $1.10 \pm 0.22$ & & & \\
\hline Mean & $1.15 \pm 0.22$ & $1.09 \pm 0.23$ & $1.19 \pm 0.24$ & & & & \\
\hline Shoulder & & & & & NS & NS & NS \\
\hline Male & $1.11 \pm 0.25$ & $1.19 \pm 0.17$ & $1.24 \pm 0.17$ & $1.18 \pm 0.21$ & & & \\
\hline Female & $1.22 \pm 0.15$ & $1.28 \pm 0.17$ & $1.19 \pm 0.17$ & $1.22 \pm 0.16$ & & & \\
\hline Mean & $1.15 \pm 0.22$ & $1.23 \pm 0.17$ & $1.21 \pm 0.17$ & & & & \\
\hline Leg & & & & & NS & NS & NS \\
\hline Male & $2.11 \pm 0.22$ & $2.13 \pm 0.27$ & $2.14 \pm 0.25$ & $2.12 \pm 0.24$ & & & \\
\hline Female & $2.18 \pm 0.25$ & $2.08 \pm 0.58$ & $2.12 \pm 0.29$ & $2.12 \pm 0.38$ & & & \\
\hline Mean & $2.14 \pm 0.23$ & $2.11 \pm 0.43$ & $2.13 \pm 0.27$ & & & & \\
\hline Ribs & & & & & NS & NS & NS \\
\hline Male & $1.16 \pm 0.24$ & $1.12 \pm 0.19$ & $1.21 \pm 0.25$ & $1.16 \pm 0.23$ & & & \\
\hline Female & $1.28 \pm 0.24$ & $1.15 \pm 0.21$ & $1.23 \pm 0.23$ & $1.22 \pm 0.23$ & & & \\
\hline Mean & $1.21 \pm 0.24$ & $1.13 \pm 0.20$ & $1.22 \pm 0.23$ & & & & \\
\hline Breast and flap & & & & & NS & NS & NS \\
\hline Male & $1.45 \pm 0.22$ & $1.43 \pm 0.28$ & $1.50 \pm 0.25$ & $1.46 \pm 0.25$ & & & \\
\hline Female & $1.56 \pm 0.25$ & $1.46 \pm 0.15$ & $1.43 \pm 0.25$ & $1.47 \pm 0.23$ & & & \\
\hline Mean & $1.50 \pm 0.24$ & $1.44 \pm 0.22$ & $1.46 \pm 0.25$ & & & & \\
\hline Loin & & & & & NS & NS & NS \\
\hline Male & $0.49 \pm 0.07$ & $0.49 \pm 0.08$ & $0.52 \pm 0.07$ & $0.50 \pm 0.08$ & & & \\
\hline Female & $0.52 \pm 0.09$ & $0.52 \pm 0.09$ & $0.49 \pm 0.09$ & $0.51 \pm 0.09$ & & & \\
\hline Mean & $0.50 \pm 0.08$ & $0.50 \pm 0.08$ & $0.50 \pm 0.08$ & & & & \\
\hline
\end{tabular}

P, Pantaneiro; TP, Texel $\times$ Pantaneiro; SIP, Santa Inês $\times$ Pantaneiro; NS, not significant.

For sex within $G$, means with different capitalized italic superscripts differ.

For $\mathrm{G}$, means with different capitalized superscripts differ.

For $\mathrm{S} \times \mathrm{G}$, means with different lower-case superscripts differ.

${ }^{*} P<0.05$.

** $P<0.01$.

${ }^{* * * *} P<0.0001$.

meat, milk, wool or skim production systems. However, studies are required to examine the effects of selection for these characteristics on the variability found in herds not evaluated until now (Costa et al., 2013).

According to Stanford et al. (1998) the fastest and the simplest way of improving the growth and carcass quality of lambs consists of using commercial crossing with the meat-type breeds. The advantage observed for TP crossing was the lower production of omental, mesenteric, perirenal and retroperitoneal fat providing leaner carcasses compared to other genotypes. The greater adiposity of $\mathrm{P}$ and SIP reflects the greater ability to store energy as fat presented by the Pantaneiro and Santa Inês genotypes, which are adapted to tropical environments. Kempster (1981) showed the differences in fat deposition in different deposits between local and specialized animals, with higher internal deposition in local breeds.

In a comparison of growth and carcass traits and non-carcass components of native Blackhead Ogaden (BO) sheep, Hararghe Highland $(\mathrm{HH})$ sheep, and Dorper sheep crossed with native Ethiopian sheep, Tsegay et al. (2013) observed a genotype influence on the characteristics evaluated, with a higher percentage of abdominal fat in native sheep and no effect of genotype on most non-carcass components. The crossing of native $\mathrm{HH}$ sheep with Dorper sheep improved animal performance, and similar to the findings of the present study, the native BO breed was similar to the Dorper $\times \mathrm{BO}$ cross for many performance characteristics and carcass results.

The use of Santa Inês sheep did not improve leg conformation; the higher leg length of SIP lambs in relation to $\mathrm{P}$ and TP lambs resulted in lower leg compactness. With the same leg weight for all animals (Table 7), TP lambs had higher LC due to their lower leg length (Table 5). This result can improve the muscle to bone ratio of lamb crossings, and it is related to the productive purpose of the genotype. The Santa Ines sheep have a double or even triple purpose for the production of meat, milk and pelt. In this sense, the Santa Inês sheep differ in morphology from Texel sheep, which feature a compact body structure focused on the production of meat.

According to Leymaster and Jenkins (1993), Texel lambs have low growth rates, lean carcasses, and high mature weights. The authors showed that there are no significant differences in pelt production and carcass composition between Texel and Suffolk lambs with the same slaughter weight. Thus, the slaughter weight used in this experiment, coupled with the fact the Texel animals show later growth, favored the production of weights and yields of cuts that were similar between genotypes.

Kremer et al. (2004) evaluated the effects of sire breed, year, sex and weight on the carcass characteristics of lambs, and found higher leg percentages for Texel $\times$ Corriedale lambs and lower loin yields compared to the TP lambs of this study. Farid (1991) evaluated the performance of three native breeds of Iran and the crossing of breeds with 
Table 7

The effect of sex (S) and genotype on cut percentage (\%)

\begin{tabular}{|c|c|c|c|c|c|c|c|}
\hline \multirow[t]{2}{*}{ Items } & \multicolumn{3}{|l|}{ Genotype (G) } & \multirow[t]{2}{*}{ Mean } & \multicolumn{3}{|l|}{$\mathrm{P}$} \\
\hline & $\mathrm{P}$ & $\mathrm{TP}$ & SIP & & $\mathrm{S}$ & G & $\mathrm{S} \times \mathrm{G}$ \\
\hline Neck & & & & & NS & NS & NS \\
\hline Male & $7.22 \pm 1.21$ & $7.36 \pm 1.40$ & $7.56 \pm 1.26$ & $7.38 \pm 1.27$ & & & \\
\hline Female & $7.14 \pm 1.80$ & $6.45 \pm 1.18$ & $6.95 \pm 1.48$ & $6.86 \pm 1.49$ & & & \\
\hline Mean & $7.19 \pm 1.45$ & $6.95 \pm 1.37$ & $7.23 \pm 1.40$ & & & & \\
\hline Shoulder & & & & & NS & NS & NS \\
\hline Male & $12.47 \pm 4.25$ & $12.00 \pm 4.06$ & $12.72 \pm 3.94$ & $12.41 \pm 4.02$ & & & \\
\hline Female & $12.30 \pm 3.41$ & $14.23 \pm 3.85$ & $12.81 \pm 3.28$ & $13.08 \pm 3.49$ & & & \\
\hline Mean & $12.40 \pm 3.87$ & $13.00 \pm 4.05$ & $12.77 \pm 3.55$ & & & & \\
\hline Leg & & & & & NS & NS & NS \\
\hline Male & $23.67 \pm 5.94$ & $21.66 \pm 7.71$ & $21.97 \pm 6.67$ & $22.47 \pm 6.70$ & & & \\
\hline Female & $22.17 \pm 6.47$ & $23.87 \pm 8.71$ & $22.74 \pm 5.86$ & $22.92 \pm 6.81$ & & & \\
\hline Mean & $23.07 \pm 6.09$ & $22.65 \pm 8.10$ & $22.39 \pm 6.16$ & & & & \\
\hline Ribs & & & & & NS & NS & NS \\
\hline Male & $12.91 \pm 3.69$ & $11.45 \pm 4.53$ & $12.56 \pm 4.74$ & $12.33 \pm 4.28$ & & & \\
\hline Female & $12.94 \pm 3.99$ & $12.76 \pm 3.49$ & $13.25 \pm 3.82$ & $13.03 \pm 3.70$ & & & \\
\hline Mean & $12.92 \pm 3.74$ & $12.04 \pm 4.08$ & $12.93 \pm 4.22$ & & & & \\
\hline Breast and flap & & & & & NS & NS & NS \\
\hline Male & $16.35 \pm 4.49$ & $14.28 \pm 4.85$ & $15.41 \pm 5.01$ & $15.39 \pm 4.76$ & & & \\
\hline Female & $15.69 \pm 4.34$ & $16.15 \pm 3.76$ & $15.30 \pm 4.10$ & $15.65 \pm 3.99$ & & & \\
\hline Mean & $16.09 \pm 4.37$ & $15.12 \pm 4.42$ & $15.35 \pm 4.47$ & & & & \\
\hline Loin & & & & & NS & NS & NS \\
\hline Male & $5.56 \pm 1.53$ & $4.99 \pm 1.95$ & $5.42 \pm 1.97$ & $5.33 \pm 1.80$ & & & \\
\hline Female & $5.24 \pm 1.61$ & $5.78 \pm 1.76$ & $5.28 \pm 1.47$ & $5.42 \pm 1.57$ & & & \\
\hline Mean & $5.43 \pm 1.54$ & $5.34 \pm 1.88$ & $5.34 \pm 1.69$ & & & & \\
\hline
\end{tabular}

P, Pantaneiro; TP, Texel $\times$ Pantaneiro; SIP, Santa Inês $\times$ Pantaneiro; NS, not significant.

For sex within $G$, means with different capitalized italic superscripts differ.

For $\mathrm{G}$, means with different capitalized superscripts differ.

For $\mathrm{S} \times \mathrm{G}$, means with different lower-case superscripts differ.

${ }^{*} P<0.05$.

${ }^{* *} P<0.01$.

*** $P<0.0001$

Corriedale and Targhee sheep. The crossing improved carcass traits without differences in the weight and yield of commercial cuts, but in contrast to the findings of the present study, the crossbreds were higher than purebreds, with the production of leaner carcasses.

Abdullah et al. (2010) studied the growth and carcass traits of pure Awassi and crossbred sheep, and observed that crossbred lambs had higher growth rates, production and yields of shoulder and rib/loin and some, testis, heart and liver. Crossing Awassi with Charolais also contributed to greater muscularity of carcasses. According to the results presented, the native breed has little aptitude for meat production, unlike the P sheep in our study, which were similar when crossed with Texel sheep, as a result of greater use of this native genotype for meat production performance.

\section{Conclusion}

The higher proportion of body fat in Pantaneiro females, resulting in early fat deposition, is indicative of their adaptation to the environment, emphasizing the importance of the breed as a maternal line in crossings. Additionally, this trait suggests that the slaughter of females should be performed at smaller body weights than those of Pantaneiro males. Texel $\times$ Pantaneiro sheep provided greater leg compactness and the production of carcasses with less body fat. The greater weight and yield of white guts of TP lambs can be advantageous as an alternative source of payment. The Texel and Santa Inês breeds are commonly used in the production of sheep meat in Brazil. As a similarity to the production and yield of commercial cuts, including those of higher value, is acquired, as demonstrated by the results, the use of Pantaneiro sheep becomes viable as a replacement for breeds selected for meat production, such as Texel, and rams and/or ewes with high market prices, such as Santa Inês.

\section{Conflict of interest}

The authors declare that there are no conflicts of interest associated with this publication.

\section{References}

Abdullah, A.Y., Kridli, R.T., Shaker, M.M., Obeidat, M.D., 2010. Investigation of growth and carcass characteristics of pure and crossbred Awassi lambs. Small Rumin. Res. 94, 167-175.

Bedhiaf-Romdhani, S., Djemali, M., Zaklouta, M., Iniguez, L., 2008. Monitoring crossbreeding trends in native Tunisian sheep breeds. Small Rumin. Res. 74, 274-278.

Boccard, R., Dumont, B.L., Peyron, C., 1964. Etude de La production de La viande chez les ovins. VIII. Relations entre les dimensions de La carcasse d'agneau. Ann. Zootech. 13, 367-378.

Costa, J.A.A., Egito, A.A., Barbosa-Ferreira, M., Reis, F.A., Vargas Junior, F.M., Santos, S.A., Catto, J.B., Juliano, R.S., Feijó, G.L.D., Ítavo, C.C.B.F., Oliveira, A.R., Seno, L.O., 2013. Ovelha Pantaneira, um grupamento genético naturalizado do Estado de Mato Grosso do Sul, Brasil. In: Palestras do VIII Congreso Latinoamericano de Especialistas en Pequeños Rumiantes y Camélidos Sudamericanos. Campo Grande, Mato Grosso do Sul, pp. 25-43. 
Crispim, B.A., Grisolia, A.B., Seno, L.O., Egito, A.A., Vargas Junior, F.M., Souza, M.R., 2013. Genetic diversity of locally adapted sheep from Pantanal region of Mato Grosso do Sul. Genet. Mol. Res. 12, 5458-5466.

Ekiz, B., Yilmaz, A., Ozcan, M., Kaptan, C., Hanoglu, H., Erdogan, I., Yalcintan, H., 2009. Carcass measurements and meat quality of Turkish Merino, Ramlic, Kivircik, Chios and Imroz lambs raised under an intensive production system. Meat Sci. 82, 64-70.

Ekiz, B., Yilmaz, A., Ozcan, M., Kocak, O., 2012. Effect of production system on carcass measurements and meat quality of Kivircik lambs. Meat Sci. 90, 465-471.

Esmailizadeh, A.K., Nemati, M., Mokhtari, M.S., 2012. Fattening performance of purebred and crossbred lambs from fat-tailed Kurdi ewes mated to four Iranian native ram breeds. Trop. Anim. Health Prod. 44, 217-223.

Farid, A., 1991. Slaughter and carcass characteristics of three fat-tailed sheep breeds and their crosses with Corriedale and Targhee rams. Small Rumin. Res. 5, 255-271.

Galal, E.S.E., Ahmed, A.M., Abdel-Aziz, A.I., Younis, A.A., 1993. Effects of increasing lambing frequency and crossbreeding on performance of sheep production systems in semi-arid environments. Small Rumin. Res. 10, 143-152.

Gökdal, Ö., Atay, O., Eren, V., Demircioğlu, S.K., 2012. Fattening performance, carcass and meat quality characteristics of Kivircik male lambs. Trop. Anim. Health Prod. 44, 14914-21496.

Kempster, A.J., 1981. Fat partition and distribution in the carcasses of cattle, sheep and pigs: a review. Meat Sci. 5, 83-98.

Kempster, S.J., Jones, D.W., Wolf, B.T., 1986. A comparison of alternative methods for predicting the carcass composition of crossbred lambs of different breeds and crosses. Meat Sci. 18, 89-110.

Kremer, R., Barbato, G., Castro, L., Rista, L., Rosés, L., Herrera, V., Neirotti, V., 2004. Effect of sire breed, year, sex and weight on carcass characteristics of lambs. Small Rumin. Res. 53, 117-124.
Kuchtík, J., Zapletal, D., Šustová, K., 2012. Chemical and physical characteristics of lamb meat related to crossbreeding of Romanov ewes with Suffolk and Charollais sires. Meat Sci. 90, 426-430.

Leymaster, K.A., Jenkins, T.G., 1993. Comparison of Texel- and Suffolksired crossbred lambs for survival, growth, and compositional traits. J. Anim. Sci. 71, 859-869.

Mariante, A.S., Egito, A.A., 2002. Animal genetic resources in Brazil: result of five centuries of natural selection. Theriogenology 57, 223-235.

National Research Council, 2007. Nutrient Requirements of Small Ruminants, 1st ed. NRC, National Academy Press, Washington, DC, USA

Pálsson, A., 1939. Meat qualities in the sheep with special reference to Scottish a breeds and crosses. J. Agric. Sci. 29, 544-626.

Souza, D.A., Selaive-Villarroel, A.B., Pereira, E.S., Osório, J.C.S., Teixeira, A. 2013. Growth performance, feed efficiency and carcass characteristics of lambs produced from Dorper sheep crossed with Santa Inês or Brazilian Somali sheep. Small Rumin. Res. 114, 51-55.

Stanford, K., Wallins, G.L., Jones, S.D.M., Price, M.A., 1998. Breeding Finnish Landrace and Romanov ewes with terminal sires for out-of-season market lamb production. Small Rumin. Res 27, 103-110.

Tsegay, T., Yoseph, M., Mengistu, U., 2013. Comparative evaluation of growth and carcass traits of indigenous and crossbred (Dorper $\times$ Indigenous) Ethiopian Sheep. Small Rumin. Res 114, 247-252.

Vargas Junior, F.M., Longo, M.L., Seno, L.O., Pinto, G.S., Ferreira, M.B., Oliveira, D.P., 2011. Potencial produtivo de um grupamento genético de ovinos nativos Sulmatogrossenses. Pubvet 30, 1197

Yakan, A., Ünal, N., 2010. Meat production traits of a new sheep breed called Bafra in Turkey 1. Fattening, slaughter, and carcass characteristics of lambs. Trop. Anim. Health Prod. 42, 751-759.

Yousefi, A.R., Kohram, H., Shahneh, A.Z., Nik-khah, A., Campbell, A.W. 2012. Comparison of the meat quality and fatty acid composition of traditional fat-tailed (Chall) and tailed (Zel) Iranian sheep breeds. Meat Sci. 92, 417-422. 